\title{
HYBRID MYTHOLOGIES: IDENTITY AND HERITAGE IN THE POETRY OF LOUISE ERDRICH
}

\author{
María Porras Sánchez \\ Universidad Complutense de Madrid
}

\begin{abstract}
This article analyzes the presence of aboriginal and classical myths in the poetry of Louise Erdrich, tokens of her double cultural heritage -Native American and German-Americanand examples of her perception of identity. The aim of this article is to research the symbolic connotations attached to Western and aboriginal myths, and to study Erdrich's appropriation of such stories. By doing so, she creates a hybrid mythology that contrasts with a contemporary background. Her poetry is an exercise of self-ethnography that empowers her hybrid heritage instead of relying in an artificial reconstruction of an ideal or mythological past, while denouncing the environmental and psychological consequences of colonization.

KEYwORDS: revisionist mythmaking, identity, cultural heritage, ethnography, colonization, Native American, hybridization.
\end{abstract}

\section{MITOLOGÍAS HÍBRIDAS: IDENTIDAD Y HERENCIA \\ EN LA POESÍA DE LOUISE ERDRICH}

\section{RESUMEN}

Este artículo analiza la presencia de mitos nativos y clásicos en la poesía de Louise Erdrich, que actúan como testimonios de su doble herencia cultural -nativo-americana y germanoamericana-y ejemplos de su percepción de la identidad. El artículo ahonda en las connotaciones simbólicas de los mitos occidentales y nativos y la apropiación que hace Erdrich de los mismos, creando una mitología híbrida que contrasta con un trasfondo contemporáneo. Así, su poesía funciona como un ejercicio de auto-etnografía que reivindica su herencia híbrida en lugar de llevar a cabo una reconstrucción artificial de un pasado idealizado o mitológico, a la vez que denuncia las consecuencias ambientales y psicológicas de la colonización.

Palabras Clave: reescritura revisionista del mito, identidad, herencia cultural, etnografía, colonización, nativo-americano, hibridación. 
As the daughter of a Ojibwe Indian mother and a German-American father, Louise Erdrich (b. 1954) has always explored identity and heritage in her writings. Better known as a novelist, she began writing poetry in the 1980s. Since then, she has authored three volumes of poems; Jacklight (1984), Baptism of Desire (1989), and Original Fire: New and Selected Poems (2003).

Rather than tracing the exact origin of the Native American myths used by Erdrich, the aim of this article is to research the symbolic connotations attached to Western and aboriginal myths, and to study Erdrich's appropriation of such stories. Why does she incorporate certain myths and mythmaking into her poetic process? What does her choice say about her heritage? What does this approach transmit in terms of identity and ideology? These are the questions I will attempt to elucidate.

\section{CRITICAL APPROACH TO IDENTITY AND HYBRIDIZATION}

Any attempt to conceptualize identity is deemed to be reductionist. For the purposes of this paper, I will refer to definitions of identity and cultural identity employed by postcolonial theory. For Stuart Hall, "identities are the names we give to the different ways we are positioned by, and position ourselves within, the narratives of the past" (Hall 223). Identity, then, is a negotiation between past and present, individual and society. In fact, the notion of cultural identity alludes both to the individual and the social, as it has two differentiated aspects: from a communal perspective, individuals locate themselves in a shared culture, whereas, from the personal perspective, individuals distinguish themselves from the rest of individuals around them (Hall 224-226). Therefore, the location and the community of the individuals affect their cultural identity, but they do not define it exclusively. Hall mentions that the notion of a common "oneness" that underlines more superficial differences has played an important role in the post-colonial struggles. In the 1970s, the Négritude movement supported the idea of a unified racial identity that all Black peoples shared. For Négritude writers, this distinctiveness also included culture and personality (Ashcroft et al. 178-179). From the 1950s to the 1970s, the Red Power movement and the American Indian Movement claimed for more rights for Native Americans within the general context of the Civil Rights movement. They advocated for a pan-Indian identity to which all the aboriginal peoples of North America could relate. However, this interpretation of identity exposed Native Americans to the dangers of essentialism. In fact, a literal or malicious interpretation of the Indian pan-identity could perpetuate some of the stereotypes Native Americans were fighting against. Many Native American writers started to explore cultural identity as part of a multi-faceted reality. For instance, Native American author and feminist activist Paula Gunn Allen links the notion of a cultural identity shared by Native Americans to the idea of recovery and rebuilding of traditions:

The women and the men of Native America are busily rebuilding their traditions, and the one most in need of rebuilding at this time is the way of the mothers and the grandmothers, the sacred way of the women [...]. We are recovering our 
heritage and uncovering the history of colonization -the history of gynocide that weakened the tribes almost to death. And we are busily stealing the thunder back, so it can empower the fires of life we tend, have always tended, as it was ever meant to. (Gunn Allen n.p.)

The interesting fact about Allen is that for her, that common "oneness" includes not only traditions and heritage but a revealing of the history of colonization. Cultural identity is then understood as a resistance against oblivion, an act of unveiling and an exercise of sorority.

The notion of heritage plays a fundamental role for Gunn Allen in the "rebuilding" and recovery of Native American cultural tradition. The National Congress of American Indians (NCAI) defines heritage in its webpage as "diverse cultures, traditions, and histories and [...] the important contributions of Native people" and has promoted in schools the initiative of the Native American Heritage Month. Although traditions, oral narratives and myths play a prominent role in most Native American communities, the fact of celebrating such heritage as the exclusive source of knowledge of these peoples touches the realm of exoticism. Although the authors of the Native American Renaissance celebrated such heritage, younger generations explore Native American heritage in a more ambivalent way. It is the case of Sto:Loh nation author Lee Maracle, who takes a different stance to that of Gunn Allen by explicitly refusing essentialism and the recovery of fake traditions based on the studies of white anthropologists. Maracle believes that Natives should "build a new society based on the positive histories of both" (116). With this statement, Maracle brings to the forefront the idea of Native American identity as a bi-cultural or hybrid product. Based in Canada, Maracle considers colonialism has been an ongoing process since the $15^{\text {th }}$ century, when French and British expeditions explored, and later settled, along the Atlantic Coast (Maracle $\mathrm{x}$-xi, 43-51). As a result of colonization, Westerners tried to eradicate certain aspects of Native American culture, with a tremendous impact on Native American identity. This is the reason why some postcolonial thinkers such as Franz Fanon, Edward Said or Homi K. Bhabha agreed upon the fact that colonial identity is constructed rather than given (Loomba 201). However, postcolonial identity becomes a different matter in which the agency of the individual is exhibited. A clear example is how different tribes have stopped using the names they were erroneously given in colonial times. As Joy Porter and Kenneth M. Roemer mention, "writers over time have changed how they identify themselves, as when Louise Erdrich moved from identifying herself as Turtle Mountain Chippewa to Turtle Mountain Ojibwe" (Porter and Roemer xxvii).

Although Maracle considers colonialism is still an ongoing phenomenon, she believes in choosing what is best from both worlds. This echoes Stuart Hall's definition of how identity should be considered: "a 'production' which is never complete but always in process, and always constituted within, not outside, representation" (Hall 222). As appealing as might seem, the idea of the subject's agency in creating a mixed identity has been rejected by some critics. Paul Gilroy, for instance, distrusts the notion of hybridity or intermixture, as it "presupposes two anterior puri- 
ties [...] I think there isn't any purity; there isn't any anterior purity [...] that's why I try not to use the word hybrid [...] Cultural production is not like mixing cocktails" (Gilroy 54-55). However, postcolonial critic Homi K. Bhabha has explored in detail the notion of hybridity and liminality applied to postcolonial identity. Bhabha calls "third space" the ambiguous area that develops when two or more individuals or cultures interact. For Bhabha, this space "challenges our sense of the historical identity of culture as a homogenizing, unifying force" (Bhabha 2006: 208). Bhabha agrees with Gilroy as he also maintains that cultures cannot be original or pure. But, unlike Gilroy, he believes that the colonizer/colonized subjectivities are interdependent and construct each other. In this sense, culture has no fixity and the same cultural signs "can be appropriated, translated, rehistoricized, and read anew" (Bhabha 2006: 208). Bhabha defines the third space as a site for encounter and negotiation of difference:

It is in the emergence of the interstices -the overlap and displacement of domains of difference- that the intersubjective and collective experiences of nationness, community interest, or cultural value are negotiated [...] The representation of difference must not be hastily read as the reflection of pre-given ethnic or cultural traits set in the fixed tablet of tradition. The social articulation of difference, from the minority perspective, is a complex, on-going negotiation that seeks to authorize cultural hybridities that emerge in moments of historical transformation. (Bhabha 1994: 2-3)

It is in this third space where hybrid identity is positioned, in the space inbetween cultures, the site for renegotiating meaning, nationness, community interest and cultural value. Author and critic Trinh Minh-Ha has also worked in a similar direction: In Framer Framed (1992), she explains that: "the notion of displacement is also a place of identity: there is no real me to return to, no whole self that synthesizes the woman, the woman of color and the writer; there are only diverse recognition of self through difference, and unfinished, contingent, arbitrary closures that make possible both politics and identity" (Minh-Ha 157). For Minh-Ha, the self is also negotiated through difference as there are no "pure" identities.

The works of Native American author Louise Erdrich can be studied within this theoretical framework of hybridization. Although sometimes literary criticism may have celebrated Native American authors emphasizing a common exoticism, critics have been less homogenizing in the last decades. For Arnold Krupat, Native American literature, "whether oral, textualized, or written, are mixed, hybrid; none are 'pure' or, strictly speaking, autonomous. Native American written literature in particular is an intercultural practice" (Krupat 21).

As we will see in the next sections, Erdrich's poetry is a good example of an intercultural practice in which the poet negotiates her multicultural, hybrid identity. Erdrich explores and celebrates it from a double perspective: by exploring Catholic traditions and Ojibwe heritage through their myths, and by creating her own hybrid mythology. As we will see, Erdrich manipulates Ojibwe and Catholic myths and traditions in order to design her own mythic and poetic universe. In 
this sense, Erdrich matches Alicia Ostriker's definition of revisionist mythmaking, by means of which "women poets deviate from or explicitly challenge the meanings attributed to mythic figures and tales" (Ostriker 1986: 215). By doing so, Erdrich negotiates her selfhood and her womanhood within the hybrid identity that myths and traditions represent. To understand how this negotiation works, a selection of Erdrich's poems would be analyzed in the next sections within the context of revisionist mythmaking and hybridization as exposed in the previous lines.

\section{NATIVE HERITAGE AND CATHOLIC FAITH: IDENTITY AND MYTHMAKING}

Erdrich's poetry emphasizes her Ojibwe heritage through her Native culture, myths and stories. Not in vain, Erdrich's main literary focus is "the world of the mixed-blood Ojibwe," as Rebecca Tillett has pointed out (Tillet 70). But, instead of being set in a remote, mythical past, or being conceived as folkloric representations of the Native mindset, myths acquire an everyday dimension, as they are part of Erdrich's portrait of contemporary Native American life. Besides, she also makes use of Western myths taken from the Classical and Catholic tradition, evoking her double heritage. In fact, "all factors of Erdrich's background, including mainstream/American/Western Civilization and Chippewa culture contribute to her source material", as Jane Hafen has argued (Hafen 148).

Erdrich was raised in the Catholic faith, even though she declares herself an agnostic. She discussed the influence of the Old Testament in her early years: "I was very young when I started reading, and the Old Testament sucked me in. I was at the age of magical thinking and believed sticks could change to serpents, a voice might speak from a burning bush, angels wrestled with people" (Halliday qtd. Kurup 22). It is interesting to notice that she places the emphasis on the narrative and imaginative power of the religious text: myths put imagination into motion, they exist outside dogma as independent stories. As such, they become an important part of the storytelling and poetic processes, acquiring a thematic presence.

Erdrich became familiar with Native American myths during her childhood in Wahpeton, in the North Dakota-Minnesota border, next to the Red River Valley ${ }^{1}$. In 1991, she recalled in an interview those early days as filled with the stories shared by her family and her community: "The people in our families made everything into a story [...] People just sit and the stories start coming, one after another [...] I suppose that when you grow up constantly hearing the stories rise, break and fall, it gets into you somehow" (Chavkin 175).

1 Wahpeton could be the town that appears some of her poems. Argus, the fictional town in which many of her novels are set -The Beet Queen (1986), Tales of Burning Love (1996), Love Medicine (1984), Tracks (1988), The Bingo Palace (1994)-, might have been modeled after Wahpeton. Erdrich does not give an exact location for Argus and the real Wahpeton never appears in her novels. For more information about geography in Erdrich's novels, see Beidler and Barton 10-16. 
Even though Erdrich began her literary career writing poetry, she does not consider herself a poet, but "a storyteller, a writer" (Coltelli 45). Already in the mid 1980 s, she declared that her poetry had influenced her storytelling process, as she tried to transfer to her fiction part of what poetry could do "metaphorically [...] sensuously, [and] physically" (Coltelli 45). ${ }^{2}$

In any case, her continuous commitment celebrating Ojibwe myths and storytelling reveals in her poetic works "the environmental consequences of colonization on the natural world", relating to "the cultural confusion and identity struggles of the colonized subject" (Kurup 92). This, as Erdrich's biographer Seema Kurup has pointed out, is "a consequence of the assimilation policies of Euro-American institutions in the New World" (Kurup 92). In this sense, her heritage is an instrument to perform social criticism, to denounce the unbalanced relationship between colonizer and colonized that has shaped the lives of the Ojibwe people.

\section{OJIBWE MYTHOLOGY AND CHRISTIAN ICONOGRAPHY IN ERDRICH'S POETRY}

In Jacklight, her first volume of poetry, Erdrich presents a wide range of speakers, as if she were willing to capture the multiple reality of Native American life and traditions from different points of view. In "Jacklight", the poem that opens the collection, Erdrich chooses a collective "we", adopting the position of a spokesperson for a whole people. In other poems, the collective "we" turns into a changing "I", a mutable self: a mythical wood-woman, as in the poem "The Woods", a sequestered Westerner, as in "Captivity" or a doe, a female antelope, in "The Strange People." She goes as far as impersonating one of the most famous Native American mythical figures, the windigo, in the homonymous poem. That is, whether contemporary, mythical, historical or autobiographical, this plurality of voices hints at the multiple identities and multiple masks the writer adopts while trying to recreate the lives and heritage of the Ojibwe people.

Going back to "Jacklight", this opening poem brings into focus two essential keys to decode Erdrich's poetry: on the one hand, there is her attitude to Native American and Euro-American history, on the other, there is the inclusion of explanatory texts before the poems. The title refers to a Chippewa word used for both flirting and hunting game. The poem presents a kind of origin myth where natives are born out of nature: "We have come to the edge of the woods, / out of brown grass where we slept, unseen / out of knotted twigs, out of leaves creaked shut, / out of hiding" (Erdrich 1984: 3). When they come out of the woods, they encounter the colonizers, a "faceless, invisible" crowd which is reduced to a general "them." This

2 Tillett maintains that, even if Erdrich has seemingly abandoned her interest in poetry in the last years, her fiction is essentially poetic in terms of style, producing "strikingly visual imagery" (Tillett 70). 
binary opposition is an inversion of the traditional colonial accounts in which natives usually are an unnamed, underrepresented crowd, referred as simply "them" versus "us." This reversal of terms becomes more complex when we turn to the title: how do we interpret this "jacklight"? Are the colonizers the prey or the hunters? The poem might be pointing out at a possible reconciliation, asking "them" to put down their guns and equipment and take "their turn to follow us" (Erdrich 1984: 4). Are the natives wooing them, when they try to lure them into the woods, or do they plan to hunt them? The question remains unanswered. Interestingly enough, the poem "The Red Sleep of Beasts", reverses the terms: this time, the speaker is a collective "we" that represents the colonizers, the first pilgrims that killed thousands of buffalo in their first incursions into the West: "We used to hunt them in our red-wheeled carts", says the speaker (Erdrich 1984: 80). Using ellipsis, buffalo are consciously unmentioned, leaving open the possibility that the poet is discussing also the "red" people, not only the "red beasts" (Erdrich 1984: 80).

In "The Red Sleep of Beasts", Erdrich implies that the frontier myth is a Western construct that romanticizes a bloody past built upon the suffering of the Native peoples and environment. This idea is emphasized by the fact that the poem is included in a section entitled "Myths". Similarly, in "Dear John Wayne" she condemns how Western films show a limited and often humiliating portrait of Native Americans. The actor John Wayne, an icon of popular culture, represents the colonizer that has spread a "disease" (Erdrich 1984: 13) and has dispossessed a people of their own identity, creating a negative perception of themselves in the minds of contemporary Natives. In this sense, Erdrich shares a similar notion of history with the postcolonial critic Homi Bhabha: instead of seeing colonialism a past event, Bhabha shows how its histories and cultures constantly intrude on the present. It is with this "intrusion" that we constantly transform our understanding of cross-cultural relations (Bhabha 1994: 1-9).

Another key that reappears in many occasions throughout Erdrich's poetry is the short explanatory text at the beginning of the poems with information about their content. In the case of "Jacklight", it is a quotation taken from an anthropology treaty of the 1950s that explains the term; in the case of "The Red Sleep of Beasts", it is an excerpt from a letter by a missionary from the 1840s. Erdrich seems to appropriate this kind of texts with a revisionist intention, turning them into a tool of self-ethnography, dismantling their hegemonic discourse power, recovering and incorporating them to her personal poetic universe, as part of her double heritage.

She also uses this framing device in the poem "Windigo", included in the section "Myths". In this occasion, the text is not taken from any other source, but it seems to be a note written by the poet herself. In the Ojibwe and Cree tradition, the Windigo is a much-feared cannibalistic being, the personification of winter famine or other winter perils. ${ }^{3}$ According to the explanatory text, this frozen demon has

3 The windigo is described in many different ways, but usually it is portrayed as a "giant with bulging eyes, a mouth filled with long, jagged teeth, and a heart of ice. Sometimes moving as a 
a man "buried deep inside" that can be released by a young girl "by forcing boiling lard down its throat" (Erdrich 1984: 79). The poem, highly musical, resembles a dark nursery rhyme in which the monster lulls and lures the child. The intentions of such an ill-famed monster remain nevertheless ambiguous: "Oh touch me, I murmured, and licked the soles of your feet. / You dug your hands into my pale, melting fur" (Erdrich 1984: 79), exclaims the Windigo, seemingly craving for some tenderness. Even though the monster steals off the child, it remains uncertain if it yields to its cannibalistic impulses or it returns the kid home, unharmed. However, the preliminary text suggests that it is finally redeemed and that its monstrous self "melts" after human contact.

Animals, so important in Native American mythologies, are recurrent elements in Erdrich's poetry. It is the case of the birds that appear in "Whooping Cranes"'. In aboriginal and other different mythologies, birds symbolize the soul, and they are considered messengers between earth and heaven. Erdrich manipulates these basic mythical figures to create a new, syncretic myth. The "hole of heaven" at the beginning of "Whooping Cranes" alludes to the entrance to heaven in many Plains origin myths (Stirrup 41). However, the allusion might be a Biblical reference as well: "It is easier for a camel to go through the eye of a needle, than for a rich man to enter into the kingdom of God" (Mark 10:25). We also find an easily identifiable Classical reference in the description of the child in the poem, who is found "in a ditch/sucking tea from a bottle" and grows "strange and secret [...] kissing his own face in the mirror" (Erdrich 1984: 73), an allusion to the myth of Narcissus (Hafen 151; Stirrup 42). One day, when the adoptive mother holds him toward heaven "so that his mother could see/you have managed to keep him fat" (Erdrich 1984: 73), he metamorphoses into a white crane and joins a flock that passes flying. Finally, the cranes cross the heavenly gates "and the sky closed after them" (Erdrich 1984: 73). Is this Native heaven or Christian heaven? The question, again is not clearly answered, even though the child's ascension might be a Christian reference. For Erdrich's scholar Jane Hafen, the child is a mediator, "an intermediary between the two cultures" (Hafen 151). Furthermore, mythical time and present time overlap in the poem; for Erdrich, this simultaneity is frequent on Native territories, as she explained in an interview: "Don't you, when you go on Indian land,

whirlwind, the creature stalked the northern woods during winter, hunting humans just as human hunted animals". As a result of famine, those people who had become cannibals were said to have "turned windigo" and were expelled from the band or killed (Lynch 124). The windigo reappears in several of Erdrich's novels including Tracks (1988) and The Antelope Wife (1998). Deborah L. Madsen discusses colonialism in Louise Erdrich's fiction as "Wiindigoo logic". The settlers' "insatiable land hunger" is represented by this monster that, the more he eats, the more he wants. See Madsen 48.

4 "Because of their ability to fly, birds were seen as intermediaries between humans and the sky spirits -as messengers that could carry prayers and pleas up to the gods and return with the gods' blessings and guidance. Powerful fliers such as Eagles and Hawks were especially associated with sky spirits" (Lynch 14). 
feel that there's more possibility, that there is a whole other world besides the one you can see and that you're very close to it?" (Chavkin 98).

In the poem "The Strange People", the female speaker metamorphoses into a doe at night. During her mythic wanderings in the woods, she meets "him", a hunter. The notion of jacklight reappears here as an extended metaphor that permeates the whole volume of poetry: does it refer to flirting or hunting? Both options are possible: the doe is chased by the hunter in the woods, and she is later carried to his house, where the animal metamorphoses into a "lean grey witch" (Erdrich 1984: 68) that confronts the hunter, even though his fate remains unknown. On the other hand, the woman goes back to her antelope self and to the woods, "asleep in clean grasses", suggesting a possible dissolution in nature. Once again, the poem is framed by an ethnographic text that records a Native story about the antelope, the so-called "strange people". On account of their beauty, they are sometimes chased by hunters who never return. Erdrich's antelope-witch seems a rereading of this earlier account, where the terms hunter-prey are reversed. If in "Windigo" the beast was redeemed, in "The Strange People", a seemingly harmless animal reveals its dark nature.

In several poems, the identification with certain animals (cranes, antelope, frogs, and owls) expands to the whole ecosystem with the mythologization of the space of the wood. Places of birth and rebirth, the woods are the cradle where the ancestors, "the tree people" lived, as in the poem "I Was Sleeping Where the Black Oaks Move." However, the wood also represents the female body, as in the poem "The Woods", where the woman is, again, the hunter of the male intruder, chasing and possessing him. These female characters might be mythical rewritings that present an empowered woman, in control of her fate and choices and even dominating men. Such vision reverts the figure of the passive Indian woman in Western tradition and the role played by women in most mythologies, as an exercise of "feminist antiauthoritarianism opposed to the patriarchal praxis", as Alicia Ostriker has pointed out (Ostriker 1986: 235).

Apart from incorporating Native American myths with a clear revisionist intention, Erdrich also includes new myths in the narrative poems devoted to Potchikoo, a series started in Jacklight and expanded in the volumes Baptism of Desire and Original Fire. These are prose poems that recall Erdrich's narrative style (Kurup 95), seemingly adapting the storytelling rhythms, humor and themes of Native American tales. Old Man Potchikoo is a mythic character of Erdrich's invention. She tells the reader about his life, his deeds, his death, his adventures in the afterlife, and his resurrection. Potchikoo is a potato boy, born out of a woman raped by the sun when she was digging in a potato field. Erdrich writes about his first love, Josette, the wooden Indian girl of a tobacco shop in Minneapolis who is brought to life when he puts a cigarette on her lips, an ironic appropriation of the stereotype of the impassible Indian. ${ }^{5}$ Then the reader learns of his premature old age, after hold-

\footnotetext{
5 Jane Hafen calls it a "wonderful play with the Noble Savage stereotype" (153).
} 
ing back a fart for too long in mass, and about his mythical mud daughters, born out of the river. Finally, he dies after his daughters sit on his lap and block the sun from him: "He hardly knew it when all three daughters laid their heads dreamily against his chest. They were cold, and so heavy that his ribs snapped apart like little dry twigs" (Erdrich 1984: 78). However, his deeds continue in the afterlife. In the Potchikoo poems, supernatural events coexist with contemporary Native American issues and Catholic references. The character of Potchikoo may be inspired by the traditional trickster in Native American folklore; the so-called Old-man is a type character in many Native American legends, the protagonist of different "whystories", the kind of folktales that are used to explain natural phenomena, animal morphology and behavior, or the origin of certain myths. Potchikoo could be also inspired by Nanabozho, the "powerful and benevolent culture hero who figures in a multitude of legends, sometimes appearing as a deceitful trickster" (Lynch 65). Regardless of its cultural source, Potchikoo embodies a monomyth, the mythical hero whose adventures, according to the great mythologist Joseph Campbell, follow a "standard path", a "formula represented in the rites of passage: separation-initiation-return" (Campbell 28).

Potchikoo, who "claims that his father is the sun in heaven that shines down on us all" (Erdrich 2003: 35), goes to Christian heaven when he dies. Saint Peter denies him the entrance on account of being "Indian" and refers him to the Indian heaven, which is "just a simple pasture gate of weathered wood" (Erdrich 2003: 42). He spends some time there and, when he is bored, he finds his way back to the world of the living. With his supernatural birth and resurrection, Potchikoo recalls a Christ figure. This might be an example of mimicry. Mimicry, according to Homi Bhabha, is the process by which the colonized subject is reproduced as "almost the same, but not quite" (Bhabha 1994: 86), becoming a "blurred copy" of the colonizer. It "represents an ironic compromise" (Bhabha 1994: 85) because mimicry is never very far from mockery, since it can appear to parody whatever it mimics. In this sense, Erdrich might be reversing the terms in the colonizer/colonized equation, mimicking Christian conventions of heaven, hell, and even the figure of Jesus Christ, who reappears in several poems of Baptism of Desire: "The Saviour", "Orozco Christ" and "Christ's Twin."

Consequently and by reversing the terms, "cultural symbols emerge as relativized through replacement" (Biróné Nagy 195). Creating her own myths, Erdrich manipulates Native and Christian tenets that speak of her multiple identities but also about her disposition to occupy a liminal third space, borrowing Bhabha's term. Hers is a liminal territory where she can experiment "defying categories" (Kurup 95). By doing so, Erdrich creates a new genre in her Pothikoo poems, halfway between prose and verse, folktale and social manifesto, Native and Christian, grotesque and humor.

In the volume Baptism of Desire, Erdrich plays again with the ordinary and mythic approach of Jacklight, even though spirituality plays a more important role and serves as a unifying thread. Catholic and Native values mingle and collide in this volume, where Western myths have a more evident presence. "Hydra," written while Erdrich was pregnant, evokes her unborn child identifying it with the ser- 
pentine water monster of the Classical tradition. At the beginning of the poem, the presence of the child echoes that of a snake [...] "uncoiling through the length of my life" (Erdrich 1989: 41). The speaker compares herself to Mary, delivering her child at Christmas in Nazareth. The Classical hydra also transforms itself into the snake of the Genesis, and it is also called "snake of the double helix" (Erdrich 1989: 46) a possible allusion to the DNA and the X chromosome. It seems that Erdrich embraces this mutable being at the same time that she embraces her motherhood and her mixed origins; she discusses the possibility of descending "into the basement of my Polish grandmother" or returning "to Wahpeton, North Dakota /, on All Soul's Night [...] and embraced the high school band leader" (Erdrich 2003: 46). Hers is a space-time travel to her origins, to her childhood and youth. These antecedents seem to converge in a mythological present:

If I finally learned to crochet

And began the world's longest scarf,

My need to perfect myself, my legacy.

If I died at the needles... (Erdrich 1989: 46)

The fear of needles evokes the fear of maternal death, while the allusions to knitting evoke a well-known figure of Classical tradition: Ariadne and her infinite thread, which becomes for Erdrich a new umbilical cord and a metaphor for her literary legacy. In fact, towards the end of "Hydra", she writes: "Snake of hard hours, you are my poetry" (Erdrich 1989: 47). For the poet, motherhood and poetry become examples of a full womanhood. Thus, far from the evil connotations of the Lernaean monster and the Biblical snake, Erdrich's hydra is a powerful symbol of female energy that she is glad and ready to embrace ${ }^{6}$.

Moreover, Catholic figures play a prominent role in this volume, especially female figures; there are poems devoted to Mary Magdalen, Teresa de Jesús ("Avila"), or Saint Claire. When these poems were compiled in Original Fire: New and Selected Poems, they all appeared within the section "The Seven Sleepers", an allusion to the Christian legend of the seven sleepers of Ephesus. Some of these poems begin with the typical explanatory note, reflecting Erdrich's interest in the imaginative and storytelling potential of such stories. In the case of "Avila", the framing text is a footnote of a biography of Teresa de Jesús, mentioning her brother, Rodrigo, who "emigrated to America in 1535 and died in a fight with Natives on the banks of the Rio de la Plata" (Erdrich 2003: 107). The poem is an imaginary letter sent by Rodrigo to her sister, recalling their childhood together and their brotherly love, ignoring more pious themes. Rodrigo's presence seems to suggest how every

${ }^{6}$ In Writing like a Woman, Alicia Ostriker discusses the importance of recording the experience of motherhood for writers. Poems involving the motherhood theme were scarce before the $1960 \mathrm{~s}$, and in the 1970s they had bad reputation among some feminists, who considered motherhood a patriarchal trap. Ostriker maintains that this is a subject "of incalculably vast significance to humanity, about which virtually nothing is known because writers have not been mothers" (Ostriker 1983: 131). 
contact with Western civilization is tainted by trauma and violence, even if there is a connection with a saint.

Together with these Christian myths, we find several poems that take the form of "heathen" prayers, such as "The Buffalo Prayer" or "Rez Litany", where Erdrich blames Euro-American colonizers for wreaking havoc on Native Americans with their assimilation policy: "Let us now pray to those beatified/within the Holy Colonial church/beginning with Saint Assimilus, / patron of residential and of government/boarding schools" (Erdrich 2003: 123). In the poem, she ironically thanks the "colonizing" saints that brought illnesses, miserable conditions and harmful policies to the Native Americans in the past, such as "Saint Bloatinus and Saint Cholestrus", "Saint Macaronia and Saint Diabeta", "Saint Microcephalia" "Saint Tremens" and "Good Saint Bingeous who fell asleep upside down on the cross and rose on the third day without even knowing he had died" (Erdrich 2003: 124). These are clear examples of what Rebecca Tillett calls the "lengthy and troubled history of federal-Indian relations and the assimilative intentions of Euro-American culture" (Tillett 70).

Besides the explicit and bitter criticism of these two poems, Erdrich's poems "do not seem to indicate conflict between Indian / Catholic worldviews, but rather, an objective acceptance of both", as biographer Frances Washburn has pointed out (Washburn 41). In a similar way, her approach to spirituality seems to be syncretic, an attempt to bring together Native and Christian faith. The poem "The Seven Sleepers" points out in that direction. In it, the speaker looks for a godly presence in nature:

\author{
I seek you, \\ Nameless one. \\ My god, my leaf. \\ I seek you in the candles of pine and in the long tongue \\ furled in sleep. I seek you in the August \\ suspension \\ of leaves as steps of sunlight \\ tottering through air (Erdrich 2003: 97)
}

\title{
4. CONCLUSIONS
}

Erdrich applies a revisionist mythmaking to Ojibwe and Catholic traditions in an attempt to "subvert and transform the life and literature women poets inherit" (Ostriker 1986: 211). Erdrich revises Western and aboriginal mythical characters, decontextualizes legends, and recreates metamorphoses and heroic journeys, calling into question conventions from different perspectives: by challenging the gender stereotypes associated to myths; by recontextualizing them through the incorporation of contemporary and ordinary elements of Native American life; by reversing Western colonial discourse, subverting stereotypes and using mimicry; and by appropriating texts by white ethnographers, undoing their hegemonic power. To sum up, by creating, in short, hybrid forms which tell us about a 
multiple heritage and identity that defy an easy classification and go beyond traditional binary oppositions.

Joseph Campbell maintained that myths could not be manufactured, ordered, or invented. At the same time, he also claimed that they were "spontaneous productions of the psyche, and each bears within it, undamaged, the germ power of its source" (Campbell 3). Erdrich definitely knows about the germ power of Native American and Western myths. She is not a manufacturer but a manipulator who effectively dismantles certain stereotypes and connotations attributed to myths and traditions. She joins other feminist Native writers such as Lee Maracle, who rejects an essentialist revival of traditions and aims at building a new community based on the positive histories of colonizer and colonized. Erdrich's exercises of self-ethnography become a way of looking at herself from a double identity, of presenting myths as an insider and an outsider, as a subject and an object at the same time. This is a way of empowering a hybrid heritage instead of relying on an artificial reconstruction of an ideal or mythological past, denouncing at the same time the environmental and psychological consequences of colonization. Both historic and identity struggles are represented through a multiplicity of speakers that tell us about a hybrid culture that, despite its challenges, is finally embraced. This plurality of voices and perspectives corresponds to the multiple aspects and narratives of Native American life that refuse to be captured into a fixed, hegemonic portrait, making, in Ostriker words, "the cultural change possible" (Ostriker 1986: 213). That is the true power of Erdrich's new hybrid mythology. 


\section{WORKS CITED}

Ashcroft, Bill, Gareth Griffiths, and Helen Tiffin. Post-Colonial Studies: The Key Concepts. $3^{\text {rd }}$ ed. London: Routledge, 2013.

Beidler, Peter G. and Gay Barton, A Reader's Guide to the Novels of Louise Erdrich. Columbia, MO: U of Missouri P, 2016.

Внавна, Homi K. "Cultural Diversity and Cultural Differences." The Post-Colonial Studies Reader, edited by Bill Ashcroft, Gareth Griffiths and Helen Tiffin, London: Routledge, 2006. 206-209.

BнaвHa, Homi K. The Location of Culture. London: Routledge, 1994.

BírónÉ NagY, Katalin. "Native American Quest for a Face: Michael Dorris and Louise Erdrich's Discovery Narrative", Neohelicon XXXV (2008) 1: 187-203.

Campbell, Joseph. The Hero with the Thousand Faces. Princeton, NY: Princeton UP, 1949.

Chavkin, Alan, and Nancy Fayl Chavkin (eds.). Conversations with Louise Erdrich and Michael Dorris. Jackson, MS: University Press of Mississippi, 1994.

Coltelli, Laura. Winged Word: American Indian Writers Speak. Lincoln, NE: U of Nebraska P, 1990.

Erdrich, Louise. Baptism of Desire: Poems. New York: HarperCollins, 1989.

Erdrich, Louise. Jacklight: Poems. London: Flamingo, 1996, [1984].

Erdrich, Louise. Original Fire: New and Selected Poems. New York: HarperCollins, 2003.

Girroy, Paul. The Black Atlantic: Modernity and Double Consciousness, London: Routledge, 1994.

Gunn Allen, Paula. "Pushing Up the Sky." In The Sacred Hoop: Recovering the Feminine in American Indian Traditions, 1986, Kindle ed., New York: Open Road Media, 2015.

Hafen, P. Jane, "Sacramental Language Ritual in the Poetry of Louise Erdrich." Great Plains Quarterly (1996): 147-155. Web <http://digitalcommons.unl.edu/greatplainsquarterly/1101>. Accessed 30 May 2018.

Hall, Stuart. "Cultural Identity and Diaspora." Identity: Community, Culture, Difference, ed. Jonathan Rutherford. London: Lawrence \& Wishart, 1990. 222-237.

Halliday, Lisa. "Louise Erdrich, The Art of Fiction No. 208” (Interview). Paris Review, 195 (Winter 2010). Web <https://www.theparisreview.org/interviews/6055/louise-erdrich-the-artof-fiction-no-208-louise-erdrich>. Accessed 30 May 2018.

Krupat, Arnold. The Turn to the Native: Studies in Criticism and Culture, Lincoln, NE: U of Nebraska P, 1996.

Kurup, Seema, Understanding Louise Erdrich. Columbia, SC: U of South Carolina P, 2015.

Loomba, Ania. Colonialism/Postcolonialism. London: Routledge, 1998.

Lynch, Patricia Ann. Native American Mythology A to Z, rev. by Jeremy Roberts, 2nd ed. New York: Chelsea Books Publishers, 2010.

Minh-HA, Trinh. Framer Framed. London: Routledge, 1992.

Madsen, Deborah L., "Discontinuous Narrative, Ojibwe Sovereignty, and the Wiindigoo Logic of Settler Colonialism”, Sail (Fall 2016) 28/3: 23-51.

Maracle, Lee. I Am Woman. A Native Perspective on Sociology and Feminism. Vancouver: Raincoast Books, 2002 [1988]. 
NCAI. "Native American Heritage Month." The National Congress of American Indians (NCAI), 2018. Web. <http://www.ncai.org/initiatives/native-american-heritage-month>. Accessed 30 May 2018.

Ostriker, Alicia Suskin. Stealing the Language. The Emergence of Women's Poetry in America. Boston, MA: Beacon Press, 1986.

Ostriker, Alicia Suskin. Writing Like a Woman. Ann Arbor, MI: The U Michigan P, 1983.

Porter, Joy, and Kenneth M. Roemer. The Cambridge Companion to Native American Literature, edited by Joy Porter. Cambridge: Cambridge UP, 2005.

Stirrup, David. Louise Erdrich. Manchester: Manchester UP, 2012.

TIllett, Rebecca. Contemporary Native American Literature. Edinburgh: Edinburgh UP, 2007.

Washburn, Frances. Tracks on a Page: Louise Erdrich, Her Life and Works. Westport, CT: Praeger, 2013. 
